\title{
WAKAF SEBAGAI BENDA PUBLIK DAN PERLINDUNGAN HUKUM KEABADIANNYA TERHADAP PERALIHAN DAN PERUBAHAN FUNGSINYA
}

\author{
Helza Nova Lita \\ Dosen Fakultas Hukum Universitas Padjadjaran \\ helza.nova@unpad.ac.id
}

\begin{abstract}
Various cases of the loss of the status of waqf objects, including the change in their function, are a number of problems that occur in the practice of waqf. For example, in the re-functioning of Hagia Sophia as a mosque which was announced by the Government of Turkey, it became news that attracted international attention, including in Indonesia, where previously the building was used as a meseum. The transition of waqf objects is interesting to study considering that the change in the function of waqf has also occurred in Indonesia. For this reason, this article will discuss how the legal protection of waqf as public good against the transfer of their status and function as waqf. The method used in this article is a legal research method with a normative juridical. Waqf is a public object whose existence and function must be protected so that it is not illegally abused. The importance of protection of waqf in a comprehensive manner includes the registration and publication. Likewise, in terms of the supervision of waqf, either from the state or the government or Nazhir, which has a direct duty to supervise and manage waqf, including the active role of the community.
\end{abstract}

Keywords: Object, Public, Protection, Waqf.

\section{A. Pendahuluan}

Wakaf dalam Islam sudah dikenal bersamaan dengan era Nabi Muhammad Saw, ditandai dengan pembangunan Mesjid Quba. Kemudian disusul dengan pembangunan Mesjid Nabawi yang dibangun di atas tanah yatim dari Bani Najjar yang dibeli oleh Rasulullah Saw. Rasulullah mewakafkan tanah yang dibelinya itu untuk dibangun masjid, dan kemudian para sahabat memberikan dukungan berupa wakaf untuk penyelesaian pembangunan masjid tersebut.

Wakaf yang pada awalnya dilakukan sebagai pemanfaatan aset individu telah mengalami berbagai perubahan, baik pada tataran paradigma maupun dalam praktik pelaksanaannya. Pada tataran paradigma, wakaf telah berkembang dari sekedar pemanfaatan suatu benda tidak bergerak berupa tanah dan bangunan, kini diupayakan dengan pemanfaatan benda tersebut agar memiliki muatan ekonomi yang bersifat produktif. Pada tataran praktik, 
wakaf kini mulai dikembangkan dalam bentuk pemanfaatan alat produksi dan alat ekonomi seperti uang, saham, dan sebagainya.

Berlakunya Undang-Undang Nomor 41 Tahun 2004 tentang Wakaf (UU Wakaf) di Indonesia, antara lain dilatarbelakangi karena praktik wakaf yang terjadi dalam kehidupan masyarakat Indonesia saat ini belum sepenuhnya berjalan tertib dan efisien. Hal ini dijelaskan dalam penjelasan umum UndangUndang Nomor Dalam berbagai kasus harta benda wakaf tidak terpelihara sebagaimana mestinya, terlantar atau beralih ke tangan pihak ketiga dengan cara melawan hukum. Keadaan demikian tidak hanya karena kelalaian atau ketidakmampuan nazhir dalam mengelola dan mengembangkan harta benda wakaf, tetapi karena juga sikap masyarakat yang kurang peduli atau belum memahami status harta benda wakaf yang seharusnya dilindungi demi untuk kesejahteraan umum sesuai dengan tujuan, fungsi, dan peruntukan wakaf.

Kasus peralihan benda wakaf serta perubahan peruntukannya, merupakan kasus yang banyak terjadi dalam praktiknya. Hal ini menarik untuk dianalisis secara yuridis bagaimana status suatu benda yang telah diwakafkan dan bagaimana upaya perlindungan hukum terhadap benda yang telah diwakafkan baik peralihannya maupun perubahan fungsinya secara melawan hukum. Artikel ini disajikan dengan mengkaji masalah tersebut dengan metode yuridis normatif yang dikaitkan dengan ketentuan hukum yang berlaku di Indonesia khususnya Undang-Undang Nomor 41 Tahun 2004 tentang Wakaf.

Wakaf (khususnya wakaf khairi) berhubungan dengan dengan ekonomi Negara, karena benda wakaf bukan lagi milik perorangan, melainkan menjadi aset publik/ milik umum. Terkait dengan wakaf sebagai aset publik, di bawah ini pembagian dua jenis aset publik sebagai berikut : ${ }^{1}$

1. Aset publik yang dimiliki negara dalam posisinya sebagai legal personality. Pemerintah boleh mendayagunakan untuk kepentingan umum, dengan syarat pendayagunaan harta tersebut sesuai dengan hukum-hukum syara'.

2. Aset Publik yang dimiliki secara khusus oleh segolongan anggota masyarakat atau organisasi. Pemanfaatan aset ini dilakukan sesuai kebutuhan. Pengelolaan aset jenis ini ditangani oleh pemerintah atau sejumlah orang yang ditunjuk di bawah pengawasan negara sesuai dengan perundang-undangan yang berlaku.

Dari dua jenis aset publik tersebut, benda yang diwakafkan merupakan aset publik yang dimiliki secara khusus oleh segolongan anggota masyarakat atau organisasi.

Roscoe Pound dalam bukunya An Introduction to The Philosophy of Law, mengklasifikasikan sifat barang-barang yang tidak dikuasai perseorangan $:^{2}$

${ }^{1}$ Husain Husain Syahatah, Perlindungan Aset Publik dalam Persfektif Hukum Islam. Terjemahan judul asli Hurmah Al-Mal Al-Am Fi Dhau' asySyariyah Al-Islamiyah, Penerjemah M. Zainal Arifin. (Jakarta: Amzah, 2005), 6.

2 Roscoe Pound, An Introduction to the Philosophy of Law, (USA : by Yale University Press,1955), 110-111. 
1. Res Communes: barang-barang yang tidak dapat dimiliki dan berhubungan dengan sifatnya itu maka disesuaikan dengan kepentingan umum;

2. Res Publicae : jika barang-barang itu dibuat atau dilihat dari sifatnya disesuaikan kepada pemakaian publik, yaitu dipakai untuk tujuan umum oleh pejabat pemerintah, atau perkauman politik;

3. Res sanctae, res sacrae, dan res religiose : jika barang-barang itu telah

dibaktikan kepada tujuan keagamaan atau diwakafkan menurut hukum agama yang tidak sesuai dengan kepemilikan privat.

Menurut Roscoe Pound, Manusia memiliki berbagai macam keinginan atau kepentingan untuk dipenuhi. Hal ini merupakan analisis awal dari munculnya teori kepentingan (theory of interests). Berbagai kepentingan ini dapat menimbulkan berbagai pertentangan atau konflik satu sama lain. Oleh karena itu hukum harus mampu melihat sejauh mungkin, agar berbagai kepentingan dan konflik tersebut tersebut dapat diatasi. ${ }^{3}$

Menurut Roscoe Pound, hukum adalah kepentingan-kepentingan tertentu (certain interests) yang menurut masyarakat harus dilindungi oleh hukum. ${ }^{4}$ Sehubungan dengan fungsi hukum, Ia menyatakan bahwa fungsi utamanya adalah untuk melindungi kepentingan, yaitu kepentingan umum, kepentingan sosial, dan kepentingan individu. ${ }^{5}$ Perlindungan ketiga kepentingan tersebut harus dilakukan secara seimbang. Keseimbangan yang harmonis inilah yang merupakan hakikat keadilan. Atas dasar inilah Roscoe Pound membuat 3 (tiga) kategori kepentingan, yaitu kepentingan individual (individual interest), kepentingan public (public interest), dan kepentingan negara sebagai penjaga kepentingan masyarakat (interest of the state as guardian). ${ }^{6}$

Roscoe Pound mendefinisikan kepentingan (interest) sebagai suatu harapan yang ingin dipenuhi manusia, baik sebagai individu, sebagai kelompok (groups) atau dalam perkumpulan (associations). Roscoe Pound mengatakan bahwa sistem hukum mencapai tujuan-tujuan tertib hukum itu dengan cara-cara sebagai berikut: ${ }^{7}$ mengakui kepentingan-kepentingan (interest) tertentu, baik kepentingan individu, kepentingan publik (public), maupun kepentingan masyarakat (social), kemudian menentukan batas-batas

${ }^{3}$ Roscoe Pound and His Theory of Social Interests, dalam Joseph Clarence, A Tesis submitted to the Faculty Graduate School of Loyola University in Partial Fulfillment of requirtments for the degree of Master of Art, (University Chicago,1958), 26.

${ }^{4}$ Hari Chand dalam Atip Latifulhayat, "Khazanah Roscoe Pound", Padjadjaran Jurnal Ilmu Hukum, (Bandung: Padjadjaran Jurnal Ilmu Hukum, Vol-1 No-2, 2014), 415.

${ }^{5}$ Ibid.

${ }^{6}$ Ibid.

${ }^{7}$ Otje Salman, Filsafat Hukum (Perkembangan\&Dinamika Masalah), (Bandung: PT. Redika Aditama, 2010), 536. 
kepentingan (interest) yang diakui, dan mengusahakan untuk menjamin kepentingan (interest) yang diakui dalam batas-batas yang ditentukan. ${ }^{8}$

Kepentingan-kepentingan umum yang penting adalah: pertama, kepentingan-kepentingan negara sebagai badan hukum dalam mempertahankan kepribadian dan hakikatnya; dan kedua, kepentingankepentingan negara sebagai penjaga kepentingan-kepentingan sosial. ${ }^{9}$ Kepentingan publik (public interest) meliputi kepentingan negara dalam kehidupan sebagai negara, dalam bertindak sebagai wali (guardian) atas kepentingan sosial (social interest), terdiri dari keamanan umum, keamanan atas lembaga-lembaga sosial, kesusilaan umum, perlindungan atas sumbersumber sosial dari kemusnahan, perkembangan sosial, kehidupan manusia pribadi.

Kepentingan individu (individu interest) terdiri dari : kepentingan pribadi, seperti perlindungan atas integritas fisik, kebebasan kehendak, reputasi, privasi, dan kebebasan untuk berkepercayaan dan berpendapat; kepentingan atas hubungan-hubungan rumah tangga, seperti perlindungan perkawinan, hubungan hukum antara orang tua dan anak; kepentingan atas materi, seperti perlindungan kekayaan, kebebasan untuk membuat testamen, kebebasan industri, dan kebebasan berkontrak.

\section{B. Pembahasan}

Wakaf secara bahasa adalah al-habs (menahan). Kata al-Waqf adalah bentuk masdar (gerund) dari ungkapan waqfu al-syai', yang berarti menahan sesuatu. ${ }^{10}$ Sedangkan menurut istilah (syara') yang dimaksud dengan wakaf sebagaimana yang didefinisikan oleh para ulama diantaranya menurut Muhammad al-Syarbini al-Khatib berpendapat bahwa:

wakaf adalah penahanan harta yang memungkinkan untuk dimanfaatkan disertai dengan kekalnya zat benda dengan memutuskan (memotong) tasharruf (penggolongan) dalam penjagaannya atas mushrif (pengelola) yang dibolehkan adanya. ${ }^{11}$

Wakaf merupakan pengelolaan harta yang menyangkut pemenuhan kepentingan umum yang diatur negara. Harta yang telah diwakafkan berubah status kepemilikannya menjadi Kepemilikan umum. Kepemilikan umum ini lahir dengan pemanfaatannya benda tersebut bagi masyarakat umum, karenanya menjadi kepentingan bersama. Negara/pemerintah dalam hal ini memiliki otoritas untuk menjaga kepemilikan umum aset wakaf ini agar sesuai dengan peruntukannya.

${ }^{8}$ Ibid, hlm. 536.

9 Stone dalam W.Friedmann, Teori dan Filsafat Hukum, diterjemahkan oleh Mohamad Arifin, (Jakarta: Rajawali, Cetakan Pertama,1990) 141.

10 Muhammad Abid Abdullah al-Kabisi, Hukum Wakaf, diterjemahkan dari Ahkam Al-Waqf fi al-Syari'ah al-Islamiyah oleh Ahrul Sani Faturrahman,dkk, (Jakarta: Dompet Dhuafa Republika dan IIman Press, 2004). 37.

11 Muhammad al-Syarbini al-Khatib dalam Hendi Suhendi, Fiqh Muamalah,(Jakarta: PT.Raja Grafindo Persada, 2010), 239. 
Berdasarkan ketentuan hukum Islam, terkait harta yang telah diwakafkan memiliki konsekuensi akibat hukum bahwa harta tersebut ditarik dari lalu lintas peredaran hukum yang seterusnya menjadi milik Allah, dikelola oleh perorangan atau lembaga nazhir, serta manfaat benda tersebut adalah untuk digunakan untuk kepentingan umum. ${ }^{12}$

Aset publik dibagi menjadi dua jenis $:^{13}$

1. Aset publik yang dimiliki negara sebagai legal personality. Dalam hal ini Pemerintah boleh mendayagunakan aset publik untuk kepentingan umum, namun mengikuti ketentuan syarat pendayagunaannya sesuai dengan hukum-hukum syara'.

2. Aset Publik yang dimiliki khusus oleh segolongan anggota masyarakat atau organisasi dimana penggunaannya dilakukan sesuai kebutuhan. Pengelolaan aset jenis ini ditangani oleh pemerintah atau sejumlah orang yang ditunjuk di bawah pengawasan negara sesuai dengan perundang-undangan yang berlaku.

Dari dua jenis aset publik diatas, benda yang diwakafkan merupakan aset publik yang dimiliki secara khusus oleh segolongan anggota masyarakat atau organisasi. Sehingga perlu dibedakan, bahwa wakaf memang merupakan benda publik, namun bukan merupakan benda publik yang dikuasai negara, karena wakaf merupakan peralihan hak secara sukarela dari kepemilikan pribadi kepada kepemilikan umum yang sudah ditentukan tujuannya dalam ikrar wakaf sesuai kehendak wakif. Negara hanya berfungsi menjaga keberlangsungan wakaf tersebut sesuai peraturan perundang-undangan yang berlaku. Sehingga negara tidak bisa mengambil alih benda wakaf sebagaimana layaknya benda publik yang dikuasai negara. Hal ini juga selaras dengan pandangan Roscoe pound dalam bukunya An Introduction to The Philosophy of Law, mengklasifikasikan sifat barang-barang yang tidak dikuasai perseorangan $:^{14}$

4. Res Communes : barang-barang yang tidak dapat dimiliki dan berhubungan ,dengan sifatnya itu maka disesuaikan dengan kepentingan umum;

5. Res Publicae : jika barang-barang itu dibuat atau dilihat dari sifatnya disesuaikan kepada pemakaian publik, yaitu dipakai untuk tujuan umum oleh pejabat pemerintah, atau perkauman politik;

6. Res sanctae, res sacrae, dan res religiose : jika barang-barang itu telah dibaktikan kepada tujuan keagamaan atau diwakafkan menurut hukum agama yang tidak sesuai dengan kepemilikan privat.

${ }^{12}$ Fikih Wakaf, Kementerian Agama Republik Indonesia. Fiqih Wakaf. Jakarta: Direktorat Jenderal Bimas Islam dan Penyelenggaraan Haji, 2003, 65.

${ }^{13}$ Husain Husain Syahatah, Syahatah, Husain Husain. Perlindungan Aset Publik dalam Persfektif Hukum Islam, Jakarta: terjemahan judul asli Hurmah Al-Mal Al-Am Fi Dhau' Asy-Syariyah Al-Islamiyah, Penerjemah M. Zainal Arifin, Penerbit Amzah, Jakarta, Cetakan I , Juli 2005, .6.

${ }^{14}$ Roscoe Pound, An Introduction to the Philosophy of Law, 1922, 1954 by Yale University Press. Revised Edition, second printing November 1955 and printed by the Colonial Press Inc, Clinton, Mass, U.S.A., 110-111. 
Pada hakikatnya res communes sebagai kepunyaan negara, adalah tidak lain dari semacam penjagaan untuk tujuan masyarakat. Pemeliharaan sumber masyarakat yang penting menghendaki pengaturan untuk penggunaan res communes untuk mencegah perbenturan serta menghindarkan pemborosan, dan menghendaki pembatasan waktu, tempat, dan orang yang boleh mengambil faedah dari barang tersebut.

Berikut ini digambarkan kaitan antara tujuan hukum untuk melindungi kepentingan para pihak dengan kepentingan para pihak dalam wakaf :

Gambar 1.2.: Implementasi Tujuan Hukum menurut Roscoe Pound dihubungkan dengan kepentingan para pihak dalam wakaf

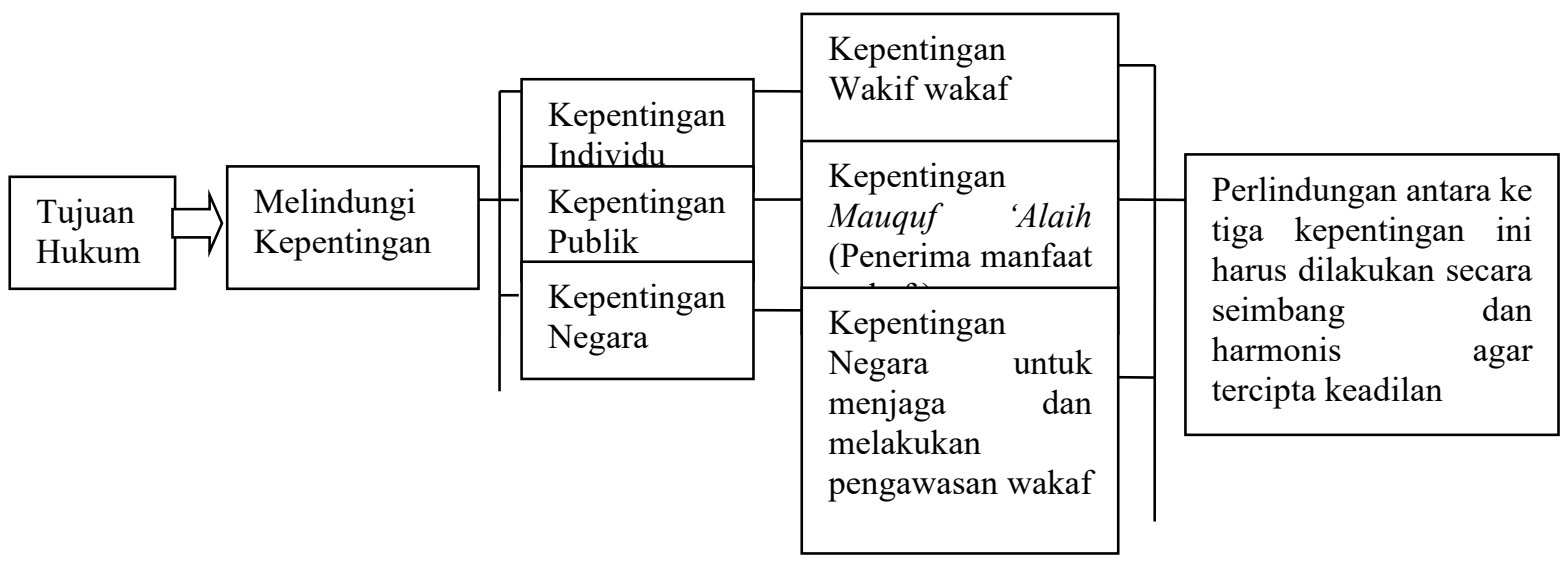

Kepentingan para pihak dalam wakaf perlu dijaga guna mencapai tertib hukum wakaf. Sebagaimana dikaitkan dengan pandangan Roscoe Pound hal tersebut dapat ditempuh dengan adanya pengakuan kepentingan para pihak dalam wakaf, yakni kepentingan individu yakni pihak wakif, kepentingan umum yakni mauquf alaih (penerima manfaat wakaf), dan kepentingan negara (dalam hal ini negara menjaga dan mengawasi kepentingan umum, agar pelaksanaan wakaf sesuai dengan peruntukannya). Kemudian ditentukan batas-batas kepentingan (interest) yang diakui para pihak dalam wakaf tersebut, dan mengusahakan untuk menjamin kepentingan (interest) yang diakui dalam batas-batas yang ditentukan.

Kepentingan pihak wakif agar sebagai benda diwakafkannya sebagai implementasi kenyakinannya untuk menjalankan agama, harus dilindungi oleh negara yang memiliki kepentingan untuk menjaga kepentingan umum, dimana benda yang telah diwakafkan menjadi benda publik. Kepentingan umum ini erat kaitannya dengan kepentingan mauquf 'alaih atau penerima wakaf. Kepentingan para pihak ini harus terjaga dengan baik agar tujuan wakaf dapat tercapai sesuai ikrar wakaf dan ketentuan perundang-undangan yang berlaku.

Wakaf yang sangat memberikan kontribusi besar bagi kesejahteraan masyarakat, seperti penyediaan fasilitas tempat ibadah seperti mesjid, tempat pendidikan, rumah sakit, serta kegiatan-kegiatan sosial lainnya. Untuk 
menjaga keberlangsungan wakaf perlu adanya perlindungan terhadap benda wakaf agar tidak terjadi penyalahgunaan seperti peralihan benda wakaf maupun perubahan fungsinya yang melanggar hukum khususnya UU Wakaf.

Dalam UU Wakaf menyebutkan pihak pihak yang terkait langsung maupun tidak langsung dalam upaya pengawasan benda wakaf, pengelolaan dan distribusinya. Pengawasan wakaf melalui Kementerian Agama sebagaimana diatur dalam Pasal 63 UU Wakaf. Demikian juga Peranan dan Tugas Badan Wakaf Indonesia dalam Pasal 49 UU Wakaf sebagai lembaga independen yang diatur dalam UU Wakaf untuk melaksanakan tugas dibidang perwakafan yang melakukan pembinaan terhadap nazhir, melakukan pengelolaan dan penggembangan harta benda wakaf berskala nasional dan internasional, memberikan persetujuan atas perubahan peruntukan dan status harta benda wakaf, dan memberikan saran dan pertimbangan kepada pemerintah dalam penyusunan kebijakan di bidang perwakafan.

Demikian juga dalam Peranan dan Pengawasan terhadap Nazhir Falsafah dasar fungsi pengawasan dalam Islam muncul dari pemahaman tanggung jawab individu, amanah, dan keadilan. ${ }^{15}$ nazhir diberikan amanah untuk mengelola dan menggembangkan aset wakaf secara langsung. Untuk itu dalam UU Wakaf juga sangat menekankan kewajiban nazhir untuk melaksanakan fungsinya sesuai amanat ikrar wakaf dan juga sanksi hukum jika terjadi penyalahgunaan.

Pembinaan dan Pengawasan terhadap benda wakaf oleh Nazhir juga diamanatkan dalam UU Wakaf. Dalam ketentuan Pasal 11 UU Wakaf Nazhir melakukan pengadministrasian harta benda wakaf, mengelola dan mengembangkan harta benda wakaf sesuai dengan tujuan, fungsi,dan peruntukannya, mengawasi dan melindungi harta benda wakaf, dan melaporkan pelaksanaan tugas kepada Badan Wakaf Indonesia. Berdasarkan Pasal 44 UU Wakaf, Nazhir dilarang melakukan perubahan peruntukan harta benda wakaf kecuali atas dasar izin tertulis dari Badan Wakaf Indonesia.

Upaya yang dilakukan untuk melindungi benda wakaf perlu dilakukan melalui pendaftaran, termasuk sertifikasi benda wakaf khususnya tanah, kemudian melakukan Pengumuman dan Publikasi Benda-benda Wakaf kepada masyarakat melalui Menteri dan Badan Wakaf Indonesia sebagaimana yang diamanatkan dalam Pasal 38 UU Wakaf.

Pendaftaran Tanah yang telah diwakafkan wakaf sangat penting dilakukan termasuk perlunya sertifikasi, agar status tanah wakaf terlindungi, dan tidak disalahgunakan. Hal ini juga dapat lebih menjamin jika terjadi sengketa dan tanah wakaf akan. Pendaftaran Tanah Wakaf saat ini dilakukan berdasarkan Peraturan Menteri Agraria dan Tata Ruang/ Kepala Badan Pertanahan Nasional Republik Indonesia Nomor 2 Tahun 2017 tentang Tata Cara Pendaftaran Tanah Wakaf di Kementerian Agraria dan Tata Ruang/ Badan Pertanahan Nasional .

${ }^{15}$ Ahmad Ibrahim Abu Sinn, Manajemen Syariah Sebuah Kajian Historis dan Kontemporer,(Jakarta: PT. Raja Grafindo Persada, 2008), 180. 
Larangan Peralihan Benda-benda Wakaf diatur dalam Pasal 40 UU Wakaf, bahwa harta benda wakaf dilarang Dijadikan jaminan, disita,dihibahkan, dijual,diwariskan, ditukar, dialihkan dalam bentuk pengalihan hak lainnya. Namun demikian untuk pengecualian perubahan status benda wakaf dalam pasal 41 UU Wakaf disebutkan, dikecualikan untuk dapat ditukar jika apabila harta benda wakaf yang telah diwakafkan digunakan untuk kepentingan umum sesuai dengan rencana umum tata ruang (RUTR) berdasarkan ketentuan peraturan perundang-undangan yang berlaku dan tidak bertentangan dengan syariah dan memperoleh izin tertulis dari Menteri atas persetujuan Badan Wakaf Indonesia.

Dalam praktiknya di Indonesia, kasus objek wakaf yang banyak terjadi khususnya masalah tanah, termasuk masalah sertifikasi Tanah Wakaf. Dari beberapa kasus dipengadilan agama sengketa mengenai sertifikasi tanah wakaf ini terjadi karena Tanah masih bermasalah atau menjadi obyek perkara di pengadilan, Terjadi perubahan penggunaan tanah, dan Alas hak atau riwayat kepemilikan tanah tidak jelas, Batas tanah tidak jelas atau tidak dapat ditunjukan oleh pemohon.Wakaf secara lisan yang belum dibuat Akta Ikrar Wakaf atau Akta Pengganti Akta Ikrar Wakaf dan wakif sudah wafat dan terjadi pengingkaran oleh ahli waris.

Berdasarkan Pasal 16 ayat (1) UU Wakaf, harta benda wakaf terdiri dari benda tidak bergerak dan benda bergerak. Dalam undang-undang harta benda wakaf tidak dibatasi pada benda tidak bergerak saja seperti tanah, tetapi juga benda bergerak seperti uang, logam mulia, surat berharga, kendaraan, hak atas kekayaan intelektual, hak sewa dan benda bergerak lain sesuai dengan ketentuan syari'ah dan peraturan perundang-undangan yang berlaku. Setiap benda yang diwakafkan harus didaftarkan, tentu saja mekanismenya dan lembaga yang terkait disesuaikan dengan jenis benda wakafnya. Namun demikian peranan Badan Wakaf Indonesia menjadi lembaga yang memiliki peran utama dalam pendaftaran benda wakaf tersebut.

Undang Undang Nomor 41 tahun 2004 tentang Wakaf dan Peraturan Pemerintah Nomor 42 Tahun 2006 tentang Pelaksanaan Undang Undang Nomor 41 Tahun 2004 tentang Wakaf, pada umumnya belum mengatur secara komperhensif terkait pendaftaran benda benda wakaf secara menyeluruh. Pengaturannya pendaftaran lebih pada tanah dan uang sebagai benda wakaf. Terkait dengan wakaf uang, berdasarkan pasal 28 UU Wakaf disebutkan bahwa wakif dapat mewakafkan benda bergerak berupa uang melalui lembaga keuangan syariah yang ditunjuk oleh Menteri. Kemudian dalam Pasal 29 ayat (1) UU Wakaf disebutkan bahwa wakaf benda bergerak berupa uang sebagaimana dimaksud dalam Pasal 28, dilaksanakan oleh wakif dengan pernyataan kehendak yang dilakukan secara tertulis. Dalam ayat (2) Pasal yang sama dinyatakan bahwa wakaf benda bergerak berupa uang sebagaimana dimaksud dalam ayat (1) diterbitkan dalam bentuk sertifikat wakaf uang. Sedangkan dalam ayat (3) Pasal yang sama diatur bahwa sertifikat wakaf uang sebagaimana dimaksud dalam ayat (2) diterbitkan dan disampaikan oleh lembaga keuangan syari'ah kepada wakif dan nazhir sebagai bukti penyerahan harta benda wakaf. Adapun ketentuan mengenai wakaf 
benda bergerak yang berupa uang akan diatur lebih lanjut dengan Peraturan Pemerintah.

Di Indonesia, wakaf uang belum lama dikenal dan diterapkan. Berbeda dengan wakaf tanah, pelaksanaan wakaf uang sedikit agak rumit karena proses perwakafannya harus melibatkan lembaga keuangan syariah. Proses pelaksanaan wakaf uang ini diatur secara jelas dalam Pasal 22 ayat (3) PP Wakaf sebagai berikut: Wakif yang akan mewakafkan uangnya diwajibkan untuk:

a. hadir di Lembaga Keuangan Penerima Wakaf Uang (LKS-PWU) untuk menyatakan kehendak wakaf uangnya;

b. menjelaskan kepemilikan dan asal-usul uang yang akan diwakafkan;

c. menyetorkan secara tunai sejumlah uang ke LKS-PWU;

d. mengisi formulir pernyataan kehendak Wakif yang berfungsi sebagai AIW.

Dalam hal Wakif tidak dapat hadir sebagaimana dimaksud pada ayat (3) huruf a, maka Wakif dapat menunjuk wakil atau kuasanya. Hal ini disebutkan dengan jelas dalam Pasal 22 ayat (4) PP Wakaf. Dalam ayat (5) Pasal yang sama disebutkan bahwa Wakif dapat menyatakan ikrar wakaf benda bergerak berupa uang kepada Nazhir di hadapan PPAIW yang selanjutnya Nazhir menyerahkan AIW tersebut kepada LKS-PWU.

Perlu adanya pengaturan lebih lanjut untuk pendaftaran dan sertifikasi benda wakaf selain tanah dan uang, agar pelaksanaan wakaf kedepan dapat menyentuh semua aspek regulasi pendaftaran dan sertifikasi benda yang dapat diwakafkan sesuai Pasal 16 UU wakaf, termasuk jenis benda wakaf surat berharga, Hak Cipta, dan sebagainya. Kerjasama Badan Wakaf dan instansi terkait sangat dibutuhkan dalam upaya pendaftaran dan sertifikasi benda wakaf tersebut. Hal ini dalam upaya untuk memperkuat legalitas benda yang diwakafkan agar terlindungi dari penyalahgunaan termasuk peralihan dan perubahan fungsinya yang melawan hukum.

Penyelesaian sengketa wakaf ditempuh melalui jalur litigasi dan non litigasi. Berdasarkan Pasal 62 UU Wakaf, Penyelesaian sengketa wakaf ini dapat dilakukan baik melalui jalur litigasi dilakukan melalui pengadilan agama, sementara non litigasi dilakukan melalui musyawarah mufakat, mediasi, dan arbitrase.Berdasarkan ketentuan UU Wakaf Sengketa wakaf dilakukan melalui jalur litigasi maupun non litigasi. Sebaiknya penyelesaian sengketa wakaf dilakukan terlebih dahulu melalui musyawarah, mediasi, arbitrase. Sengketa wakaf termasuk kewenangan Pengadilan Agama berdasarkan Pasal 62 ayat (2) UU Nomor 41/2004 dan penjelasan pasal tersebut.

UU Wakaf memuat Sanksi terhadap penyelewengan pelaksanaan wakaf menurut UU Wakaf baik pidana maupun adminitrasi. Dalam Pasal 67 UU Wakaf memuat sanksi pidana terhadap Setiap orang yang dengan sengaja menjaminkan, menghibahkan,menjual,mewaris- kan, mengalihkan dalam bentuk pengalihan hak lainnya harta benda wakaf yang telah diwakafkan atau tanpa izin menukar harta benda wakaf yang telah diwakafkan, termasuk orang yang dengan sengaja menghibah peruntukan harta benda 
wakaf tanpa izin, dan orang yang dengan sengaja menggunakan atau mengambil fasilitas atas hasil pengelolaan dan pengembangan harta benda wakaf melebihi jumlah yang ditentukan sebagaimana dimaksud dalam Pasal 12 UU Wakaf. Sementara untuk Sanksi Administrasi dalam Pasal 68 UU Wakaf terkait sanksi administratif atas pelanggaran tidak didaftarkannya harta benda wakaf oleh lembaga keuangan syariah dan PPAIW sebagaimana

dimaksud dalam Pasal 30 dan Pasal 32 UU Wakaf. Sanksi administratif berupa peringatan tertulis, penghentian sementara atau pencabutan izin kegiatan di bidang wakaf bagi lembaga keuangan syariah, penghentian sementara dari jabatan atau penghentian dari jabatan PPAIW.

Sebagai penutup dari uraian bagian pembahasan mengenai perlindungan benda wakaf, hal yang paling penting dalam upaya perlindungan benda wakaf adalah bagaimana agar pengelolaan wakaf memenuhi Asas Akuntabilitas dimana pengelolaan wajaf dapat dipertanggungjawabkan dan diakses oleh masyarakat secara transparan, sehingga timbul kepercaaan masyarakat baik terhadap wakaf maupun Lembaga wakaf itu sendiri. Wujud dari akuntabilitas adalah transparansi baik dalam hal pengelolaan maupun pengambilan manfaat wakaf. Hal ini akan meningkatkan kepercayaan masyarakat terhadap Lembaga wakaf, dan menimbulkan motivasi untuk berwakaf secara luas.

\section{Kesimpulan}

Pengawasan terhadap aset-aset wakaf serta pengelolaan dan penyalurannya merupakan bagian yang sangat penting untuk melindungi asetasaet wakaf tersebut agar sesuai dengan peruntukannya. Undang Undang Nomor 41 Tahun 2004 tentang Wakaf, pada umumnya belum mengatur secara komperhensif terkait pendaftaran benda benda wakaf secara menyeluruh. Pengaturannya pendaftaran lebih pada tanah dan uang, untuk itu diperlukan pengaturan lebih lanjut pendaftaran dan sertifikasi benda wakaf selain tanah dan uang, agar pelaksanaan wakaf kedepan dapat menyentuh semua aspek regulasi pendaftaran dan sertifikasi benda yang dapat diwakafkan sesuai Pasal 16 UU wakaf.

\section{Daftar Pustaka}

Ahmad Ibrahim Abu Sinn. Manajemen Syariah Sebuah Kajian Historis dan Kontemporer. Jakarta: PT. Raja Grafindo Persada. 2008.

Atip Latifulhayat. "Khazanah Roscoe Pound", Padjadjaran Jurnal Ilmu Hukum. Bandung: Padjadjaran Jurnal Ilmu Hukum, Vol-1 No-2. 2014.

Fikih Wakaf. Kementerian Agama Republik Indonesia. Fiqih Wakaf. Jakarta: Direktorat Jenderal Bimas Islam dan Penyelenggaraan Haji. 2003. 
Husain Husain Syahatah. Perlindungan Aset Publik dalam Persfektif Hukum Islam. Terjemahan judul asli Hurmah Al-Mal Al-Am Fi Dhau' asySyariyah Al-Islamiyah, Penerjemah M. Zainal Arifin. Jakarta: Amzah. 2005.

Hendi Suhendi. Fiqh Muamalah. Jakarta: PT.Raja Grafindo Persada. 2010.

Joseph Clarence, A Tesis submitted to the Faculty Graduate School of Loyola University in Partial Fulfillment of requirtments for the degree of Master of Art. University Chicago. 1958.

Muhammad Abid Abdullah al-Kabisi. Hukum Wakaf, diterjemahkan dari Ahkam Al-Waqf fi al-Syari'ah al-Islamiyah oleh Ahrul Sani Faturrahman,dkk. Jakarta: Dompet Dhuafa Republika dan IIman Press. 2004.

Otje Salman, Filsafat Hukum (Perkembangan\&Dinamika Masalah). Bandung: PT. Redika Aditama, 2010.

Peraturan Pemerintah Nomor 42 tahun 2006 tentang Pelaksanaan Undang-Undang Nomor 41 tahun 2004 tentang wakaf (Lembaran Negara Republik Indonesia Tahun 2006 Nomor 105; Tambahan Lembaran Negara Republik Indonesia Nomor 4667).

Roscoe Pound. An Introduction to the Philosophy of Law. USA : by Yale University Press. 1955.

Undang-Undang Nomor 41 Tahun 2004 tentang Wakaf (Lembaran

Negara Republik Indonesia Tahun 2004 Nomor 159; Tambahan Lembaran Negara Republik Indonesia Nomor 4459)

W.Friedmann, Teori dan Filsafat Hukum, diterjemahkan oleh Mohamad Arifin. Jakarta: Rajawali, Cetakan Pertama.1990. 